2014

\title{
Combating Maritime Piracy: Inter-Disciplinary Cooperation and Information Sharing
}

Yaron Gottlieb

Follow this and additional works at: https://scholarlycommons.law.case.edu/jil

Part of the International Law Commons

\section{Recommended Citation}

Yaron Gottlieb, Combating Maritime Piracy: Inter-Disciplinary Cooperation and Information Sharing, 46 Case W. Res. J. Int'l L. 303 (2013)

Available at: https://scholarlycommons.law.case.edu/jil/vol46/iss1/14

This Article is brought to you for free and open access by the Student Journals at Case Western Reserve University School of Law Scholarly Commons. It has been accepted for inclusion in Case Western Reserve Journal of International Law by an authorized administrator of Case Western Reserve University School of Law Scholarly Commons. 


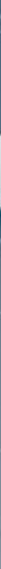

Combating Maritime Piracy:

INTER-DisCIPLINARY COOPERATION AND INFORMATION SHARING

$$
\text { Yaron Gottlieb }
$$




\section{Combating Maritime Piracy: INTER-DISCIPLINARY COOPERATION AND INFORMATION SHARING}

\section{Yaron Gottlieb*}

In recent years, maritime piracy has reemerged as a serious threat to the international community, particularly following the significant increase in incidents of maritime piracy and armed robbery at sea that occurred off the coast of Somalia and in the Gulf of Guinea. As presented in this article, international cooperation is indispensable for combating piracy. To that end, the article argues that a duty to cooperate in the repression of piracy is moored in various international instruments - notably in Article 100 of the U.N. Convention on the Law of the Sea (UNCLOS) - as well as in general principles of international law. It requires states to adhere to due diligence 'best efforts' standards, which, in the context of maritime piracy, entail exercising sincere, concerted, and proactive efforts. The duty to cooperate should serve as a guiding principle in identifying the specific obligations imposed on states. Among those specific obligations is the duty to share relevant information that can assist in preventing piracy attacks and in facilitating prosecution of suspected pirates. It is further submitted that successful undertakings to fight maritime piracy necessitate inter-disciplinary cooperation, namely cooperation among entities whose expertise generally lies in different fields. The article further discusses the main challenges for information sharing and proposes solutions to meet those challenges.

Senior Counsel, Office of Legal Affairs, ICPO-INTERPOL. I would like to thank Professor Wui Ling Cheah of the National University of Singapore and Ms. Rachel Berman-Vaporis of Case Western Reserve University School of Law for their valuable comments. 


\section{CONTENTS}

I. INTRODUCTION

II. Combating Maritime Piracy: The Duty to Cooperate

A. The Primary Legal Sources Underlying the Duty to Cooperate

B. Interpretation of the Duty to Cooperate: The Applicable Legal Test...308

C. Article 100 as the Guiding Principle in Identifying the Specific Duties Imposed on States....

III. The Duty to Share Information as a Specific Obligation under the General Duty to Cooperate.

IV. The Nature of Cooperation: A Call for Holistic INTER-DISCIPLINARY COOPERATION

V. Challenges in Sharing Information in the Fight Against PIRACY ............................................................... 320

A. Scope of the Duty to Share Information and the "National Security" Exception

B. Challenges Deriving from the Nature of the Crime and the Entities Involved in Counter-Piracy Operations

1. Navies carrying out law enforcement activities

2. Interaction with the shipping industry

C. The Proliferation of Information Networks and its Discontents

VI. Conclusion

\section{INTRODUCTION}

In recent years, maritime piracy has reemerged as a serious threat to the international community, notably following the significant increase in incidents of maritime piracy and armed robbery at sea that occurred off the coast of Somalia and in the Gulf of Guinea. As presented in this article, international cooperation is indispensable for combating piracy. To that end, this article argues that a duty to cooperate in the repression of piracy exists under international law. This duty, as articulated in Article 100 of the U.N. Convention on the Law of the Sea (UNCLOS), should serve as a guiding principle in identifying the specific obligations imposed on states. Among these specific obligations is the duty to share relevant information that can assist in preventing piracy attacks and in facilitating prosecution of suspected pirates. It is further submitted that successful undertakings to fight maritime piracy necessitate inter-disciplinary cooperation, namely cooperation among entities with expertise in different fields. This article further discusses the main challenges associated with information sharing, and it proposes solutions to meet them. 


\section{Combating Maritime Piracy: The Duty to Cooperate}

\section{A. The Primary Legal Sources Underlying the Duty to Cooperate}

Combating maritime piracy requires commitment and active engagement by states. As indicated by Mr. Helmut Tuerk, the honorable justice of the International Tribunal for the Law of the Sea, "[t]he practice of piracy has been widespread over the centuries and continues to be a menace. As a result, every State not only has a right, but also a duty, to take action to curb piratical activities."

States are expected to take measures on both the domestic levelfor example, by criminalizing piratical acts ${ }^{2}$ - and on the international level. The key element of the latter is international cooperation, whether directly among states or through the involvement of international organizations and other mechanisms created by states.

Indeed, international instruments repeatedly refer to the importance of international cooperation in the repression of maritime piracy. Thus, for example, the Convention for the Suppression of Unlawful Acts Against the Safety of Maritime Navigation ("SUA Convention") provides in Article 13 that state parties shall cooperate in the prevention of the offences defined by that convention. ${ }^{3}$

1. Helmut Tuerk, Combating Terrorism at Sea-The Suppression of Unlawful Acts Against the Safety of Maritime Navigation, 15 U. MiAmI INT'L \& COMP. L. REV. 337, 342 (2008).

2. See S.C. Res. 1918, para. 2, U.N. Doc. S/RES/1918 (Apr. 27, 2010) (calling on "all States, including States in the region, to criminalize piracy under their domestic law"). The UNSC reiterated this call in later resolutions. See, e.g., S.C. Res. 2077, para. 18, U.N. Doc. S/RES/2077 (Nov. 21, 2012) (reiterating the call on "all States to criminalize piracy under their domestic law").

3. Convention for the Suppression of Unlawful Acts Against the Safety of Maritime Navigation art. 13, opened for signature Mar. 10, 1988, 1678 U.N.T.S. 221 (entered into force Mar. 1, 1992) [hereinafter SUA Convention]. Though the SUA Convention does not use the term "piracy," at least some of the offences listed in Article 3 of the Convention such as the seizure of a ship by force are undoubtedly applicable to piratical acts. See id. at 224. On the application of the SUA Convention in the fight against maritime piracy see, inter alia, Milena Sterio, Piracy Off the Coast of Somalia: The Argument for Pirate Prosecutions in the National Courts of Kenya, the Seychelles, and Mauritius, 4 Amsterdam L.F. 104, 121 (2012) (finding that "SUA may prove to be a more useful model for the prosecution of pirates than UNCLOS"); Cheah Wui Ling, Extradition and Mutual Legal Assistance in the Prosecution of Serious Maritime Crimes: A Comparative and Critical Analysis of Applicable Frameworks 9-10, 13, Hague ACAdEMY RESEARCH SERIES (forthcoming 2014), available at http://ssrn.com/ abstract $=2259753$ ("The 1988 SUA is particularly noteworthy because it addresses a number of cooperation issues that are encountered at sea."). 
Similarly, the U.N. Security Council (UNSC), in its series of resolutions related to the threats of piracy and armed robbery at sea off the coast of Somalia (and more recently in the Gulf of Guinea), urged all states to cooperate with each other and with international organizations in combating acts of piracy and armed robbery at sea. ${ }^{4}$ The importance of international and regional cooperation in this domain was also highlighted by the U.N. General Assembly in its resolutions on oceans and the law of the sea..$^{5}$

Notably, Article 100 of UNCLOS, titled "Duty to cooperate in the repression of piracy," specifies that "[a]ll States shall cooperate to the fullest possible extent in the repression of piracy on the high seas or in any other place outside the jurisdiction of any State."

The duty to cooperate is at the core of the piracy section of UNCLOS. Indeed, it is the first provision of this section, thereby providing an appropriate benchmark as well as framework for the substantive provisions that follow. Moreover, while international cooperation is a common theme of $\mathrm{UNCLOS}^{7}{ }^{7}$ Article 100 is unique in two ways. First, it is the only provision in UNCLOS in which the title is the duty to cooperate. ${ }^{8}$ Secondly, it uses the strongest wording

4. With regard to the situation in Somalia, see, for example, S.C. Res. 1816, para. 3, U.N. Doc. S/RES/1816 (June 2, 2008). All UNSC resolutions that followed on this matter highlighted the importance of international cooperation. With regard to the situation in the Gulf of Guinea, see S.C. Res. 2018, paras. 4, 5, U.N. Doc. S/RES/2018 (Oct. 31, 2011); S.C. Res. 2039, pmbl., U.N. Doc. S/RES/2039 (Feb. 29, 2012).

5. See G.A. Res. 63/111, ๆ 61, U.N. Doc. A/RES/63/111 (Dec. 5, 2008) ("[The General Assembly] [r]ecognizes the crucial role of international cooperation at the global, regional, subregional and bilateral levels in combating, in accordance with international law, threats to maritime security, including piracy, armed robbery at sea ...."). The General Assembly reiterated this point in its annual resolutions on oceans and the law of the sea. See G.A. Res. 66/231, I 81, U.N. Doc. A/RES/66/231 (Dec. 24, 2011); G.A. Res. 67/78, ๆ 88, U.N. Doc. A/RES/67/78 (Dec. 11, 2012).

6. U.N. Convention on the Law of the Sea art. 100, opened for signature Dec. 10, 1982, 1833 U.N.T.S. 397 (entered into force Nov. 16, 1994) [hereinafter UNCLOS].

7. See Yoshifumi Tanaka, The International LaW of the Sea 4 (2012) (explaining how international cooperation and spatial distribution of national jurisdiction are the two basic functions of UNCLOS).

8. Compare with other cooperation-related sections or provisions in UNCLOS such as Section 2 (titled Global and Regional Co-operation) of Part XII (Protection and Preservation of the Marine Environment) or Section 2 (titled "International Co-operation") of Part XIII (Marine Scientific Research). The titles of those provisions do not make a specific reference to the "duty to cooperate." UNCLOS, supra note 6, 1833 U.N.T.S. at 479, 496. 
found in UNCLOS with regard to this obligation; namely, that all states shall cooperate "to the fullest possible extent."

Article 100 of UNCLOS contains the precise wording of Article 14 of the 1958 Geneva Convention on the High Seas (HSC) ${ }_{10}^{10}$ which in turn incorporated (again, verbatim) the corresponding article adopted by the International Law Commission (ILC) on the law of the sea. ${ }^{11}$ All of these provisions went beyond the proposal put together in the scholarly work known as the Harvard Research Draft, ${ }^{12}$ which later served as the basis for the discussions of piracy by the ILC and the negotiations of the piracy provisions in the HSC. Article 18 of the Harvard Research Draft provided that "[t]he parties to this convention agree to make every expedient use of their powers to prevent piracy, separately and in co-operation." The commentary to this provision underscored that Article 18 imposes on states only "a general discretionary obligation to discourage piracy by exercising their rights of prevention and punishment as far as is expedient." ${ }^{13}$ By establishing a duty to cooperate, UNCLOS and the HSC therefore send a clearer message than originally foreseen in the proposal of the Harvard Research Draft.

Both UNCLOS and HSC, however, did not set out the precise obligations that fall within the scope of the general duty to cooperate ${ }^{14}$ thereby leaving this provision open to interpretation with

9. UNCLOS, supra note 6, art. 100, 1833 U.N.T.S. at 436 (emphasis added). Compare with the wording of other UNCLOS provisions mentioning that "States shall co-operate" (Articles 108 and 109) or "should co-operate" (Article 123) or even "may co-operate" (e.g., Article 129). Other provisions provide that "States shall co-operate actively" (Article 273) or refer to cooperation "to the extent possible" (Article 199). None of these therefore contain the clearest instruction on cooperation as prescribed by Article 100. Id. at 437-38, 443, 479, 505.

10. Convention on the High Seas art. 14, opened for signature Apr. 29, 1958, 13 U.S.T. 2312, 450 U.N.T.S. 82 (entered into force Sept. 30, 1962).

11. Report of the International Law Commission to the General Assembly, 11 U.N. GAOR Supp. No. 9, art. 38, U.N. Doc. A/3159 (1956), reprinted in [1956] 2 Y.B. Int'l L. Comm'n 253, 282, U.N. Doc. A/CN.4/SER.A/1956/Add.1 [hereinafter 1956 ILC Report].

12. Harvard Research in Int'l Law, Draft Convention on Piracy with Comments, 26 Am. J. InT'L L. Supp. 741 (1932); Myra Williamson, Terrorism, WAR, AND INTERnational LAW: The LEgality of THE UsE of Force Against Afghanistan in 2001, at 95 (2009) (describing the Harvard Research Draft as seminal because it comprehensively discussed all angles of maritime piracy, which were later incorporated by the ILC and HSC).

13. Harvard Research in Int'l Law, supra note 12, at 746, 760.

14. Compare to other sections of UNCLOS that specify the various areas and means of cooperation such as Article 123 on cooperation of states bordering enclosed or semi-enclosed seas, or Article 143 on collaboration 
regard to the means that states should employ to sufficiently fulfill their obligation. At the very least, however, it is evident that inaction or failure to cooperate in response to piratical acts - where both the factual circumstances and the applicable legal framework allow for action and cooperation - cannot be reconciled with the duty as prescribed by Article 100. The ILC, in its above commentary, clearly stated that "[a]ny State having an opportunity of taking measures against piracy, and neglecting to do so, would be failing in a duty laid upon it by international law." 15 Similarly, Mr. Jack Lang, the Special Adviser appointed by the U.N. Secretary General to address the legal issues related to piracy off the coast of Somalia, underscored that the degree of flexibility provided by the wording of Article 100 "should not be used as a pretext for failure to prosecute." ${ }^{" 16}$ Professor Rüdiger Wolfrum, the honorable justice and former President of the International Tribunal for the Law of the Sea, echoed this approach, stating that "a ship entitled to intervene in cases of piracy may not, without good justification, turn a blind eye to such acts." 17 Professor Wolfrum went a step further by asserting that "[t] urning a blind eye to the activities of pirates is in itself an act of piracy," 18 and by suggesting that states permitting piracy activities may be subject to countermeasures and also, theoretically, to an intervention by the UNSC..$^{19}$

\section{B. Interpretation of the Duty to Cooperate: The Applicable Legal Test}

Notwithstanding UNCLOS' shortcomings in failing to detail the specific obligations within the scope of the general duty to cooperate, certain conclusions can be reached regarding the nature of the duty, the applicable legal test, and the specific actions expected from states, such as the duty to share relevant information. ${ }^{20}$

in the field of marine scientific research. UNCLOS, supra note 6,1833 U.N.T.S. at $443,448$.

15. 1956 ILC Report, supra note 11, at 282.

16. Special Advisor to the Secretary-General on Legal Issues Related to Piracy off the Coast of Somalia, Annex Report to the Letter dated Jan. 24, 2011 from the Secretary-General to the President of the Security Council, I 49, U.N. Doc. S/2011/30 (Jan. 25, 2011) (by Jack Lang).

17. Rüdiger Wolfrum, Fighting Terrorism at Sea: Options and Limitations Under International Law, ITLOS 4, http://www.itlos.org/fileadmin/itlos/ documents/statements_of_president/wolfrum/doherty_lectire_130406 _eng.pdf (last visited Feb. 28, 2014).

18. Id. at 5 .

19. Id.

20. See infra Part III and discussion on duty to share information. 
In this respect, Article 100 should be interpreted broadly. This derives from the provision's wording (duty to cooperate "to the fullest possible extent") as well as from the underlying rationale of the piracy section of UNCLOS; namely, ensuring the international community's common interest in protecting the freedom of navigation and safety of persons at sea. ${ }^{21}$

Further, while Article 100 does not create an absolute obligation, its clear wording entails the existence of a presumption of cooperation in the face of piracy. This presumption also derives from the general principle of good faith in fulfilling treaty obligations, long recognized as "[o]ne of the basic principles governing the creation and performance of legal obligations, whatever their source ..." ${ }^{\prime 22}$ and explicitly mentioned in UNCLOS. ${ }^{23}$ Thus, a state that was in a position to act and failed to do so carries the burden of justifyingbased on factual, legal, or other grounds - its lack of action.

For the purpose of assessing compliance with the duty to cooperate, this article proposes the application of the due diligence principle. This fundamental principle of international law ${ }^{24}$ was used as early as $1871,{ }^{25}$ has been frequently applied in different fields such

21. See Douglas Guilfoyle, Shipping Interdiction and the LaW of the SEA 38 (2009) (stating that "the rule against piracy exists to protect the freedom of navigation and the safety of persons upon the high seas").

22. Nuclear Tests (N.Z. v. Fr.), Judgment, 1974 I.C.J. 457, ๆ 49 (Dec. 20). With regard to performing treaty obligations in good faith see also Vienna Convention on the Law of Treaties art. 26, opened for signature May 23, 1969, 1155 U.N.T.S. 331 ("Every treaty in force is binding upon the parties to it and must be performed by them in good faith."). On the principle of good faith in the context of international cooperation, see Report of the International Law Commission to the General Assembly, 56 U.N. GAOR Supp. No. 10, 396, U.N. Doc. A/56/10 (2001), reprinted in [2001] 2 Y.B. Int'l L. Comm'n 1, 155, U.N. Doc. A/CN.4/SER.A/2001/Add.1 (Part 2) [hereinafter 2001 ILC Report].

23. UNCLOS, supra note 6, art. 300, 1833 U.N.T.S. at 516 ("States Parties shall fulfil in good faith the obligations assumed under this Convention and shall exercise the rights, jurisdiction and freedoms recognized in this Convention in a manner which would not constitute an abuse of right.").

24. Robert P. Barnidge, Jr., The Due Diligence Principle Under International Law, 8 INT'L COMMUNITY L. REV. 81, 121 (2006) (quoting Luigi Condorelli, The Imputability to States of Acts of International Terrorism, 19 IsR. Y.B. H.R. 233, 240 (1989)).

25. The 1871 Treaty of Washington mentioned due diligence in reference to the responsibility of a neutral state for damages caused by private individuals acting within its jurisdiction. See Treaty of Washington, U.S.-Gr. Brit., art. VI, May 8, 1871, 17 Stat. 863, T.S. No. 133. A year later, the treaty and this concept were subject to an international arbitration (the Alabama Arbitration) between the U.S. and Great Britain over the alleged failure of Great Britain to fulfill its duty of neutrality during the American Civil War. See Alabama Claims of U.S. 
as environmental law, as well as invoked by international tribunals in various cases. ${ }^{26}$ In some instances the principle has been mentioned in an international instrument, ${ }^{27}$ yet an explicit reference is not required as a precondition of utilizing it as the relevant standard. For example, in its commentary to the Draft Articles on Prevention of Transboundary Harm from Hazardous Activities ("Draft Articles"), the ILC often refers to this concept, even though it is not expressly mentioned in the Draft Articles. Moreover, the ILC commentary to the Draft Articles concluded that "[a]n obligation of due diligence as the standard basis for the protection of the environment from harm can be deduced from a number of international conventions." 28 As an example of such a convention, the commentary mentions Article 194(1) of UNCLOS ("Measures to prevent, reduce, and control pollution of the marine environment"), which does not expressly use the term due diligence. ${ }^{29}$

The definition of this principle has been the subject of discussions from the very early days of its existence. ${ }^{30}$ Maria Flemme proposed to

Against Great Britain (U.S. v. Gr. Brit.), 29 R.I.A.A. 125, 131 (Treaty of Washington Trib. Arb. 1872).

26. See, e.g., Pulp Mills on the River Uruguay (Arg. v. Uru.), Judgment, 2010 I.C.J. 14, ๆ 101, 187 (Apr. 20) (calling for both parties to exercise due diligence when taking measures to preserve the ecological balance of the River Uruguay); Responsibilities and Obligations of States Sponsoring Persons and Entities with Respect to Activities in the Area, Case No. 17, Advisory Opinion of Feb. 1, 2011, 11 ITLOS Rep. 10, ๆ 110-20 [hereinafter Responsibilities and Obligations Advisory Opinion] (reiterating and explaining the principle of due diligence).

27. For example, the International Law Commission's Draft Articles on the Law of the Non-Navigational Uses of International Watercourses provides in draft Article 7.1 (titled "Obligation not to cause significant harm") that "[w]atercourse States shall exercise due diligence to utilize an international watercourse in such a way as not to cause significant harm to other watercourse States." Report of the International Law Commission to the General Assembly, 49 U.N. GAOR Supp. 10, U.N. Doc. A/49/10 (1994), reprinted in [1994] 2 Y.B. Int'l L. Comm'n 1, 102, U.N. Doc. A/CN.4/SER.A/1994/Add.l (Part 2). See also UNIDROIT, Convention on Stolen or Illegally Exported Cultural Objects, art. 4(1) (June 24, 1995) (stipulating that a possessor of a stolen cultural object has a right to restitution upon returning the object if he/she proves, inter alia, the exercise of due diligence when acquiring the object).

28. 2001 ILC Report, supra note 22, at 154 (citing commentary to Article 3 of the Draft Articles on Prevention of Transboundary Harm from Hazardous Activities).

29. Id. at 154 n.880; UNCLOS, supra note 6, art. 194, 1833 U.N.T.S. at 478.

30. In the 1872 Alabama Arbitration, the parties to the dispute (the U.S. and Great Britain) presented different definitions of the due diligence concept as referred to in the 1871 Treaty of Washington. See Alabama Claims, 29 R.I.A.A. at 129 (holding that due diligence should be 
view due diligence as signifying "the conduct to be expected of good government in order to effectively protect other States and the global environment." 31 She also suggested that the concept entails "a minimum level of efforts which a State must undertake to fulfil [sic] its international responsibilities." 32 In its commentary to Article 3 of the Draft Articles, the ILC defined a higher threshold than Flemme's "minimum level of efforts," namely that of "reasonable efforts." 33 Elsewhere, it has been suggested that "the due diligence obligation requires the state's best effort $[s],{ }^{, 34}$ a position also reflected in the Responsibilities and Obligations Advisory Opinion by the International Tribunal of the Law of the Sea. ${ }^{35}$

As indicated earlier in this article, UNCLOS uses the strongest wording when referring to the duty to cooperate in the repression of piracy (cooperation "to the fullest possible extent"). It is also noteworthy that among the factors to be considered when determining the applicable standard of due diligence are the specific risks generated by the case or activity at hand. ${ }^{36}$ In that regard, it is

"exercised by neutral governments in exact proportion to the risks to which either . . . may be exposed, from a failure to fulfill the obligations of neutrality" after the parties in this suit presented different definitions of the concept as referred to in the 1871 Treaty of Washington).

31. Maria Flemme, Due Diligence in International Law, at 12 (Spring 2004) (unpublished M. A. thesis) (on file with Lund University), available at http://www. lunduniversity.lu.se/o.o.i.s?id=24965\&postid $=1557482$.

32. Id. at 1 .

33. 2001 ILC Report, supra note 22, at 154 ("In the context of the present articles, due diligence is manifested in reasonable efforts by a State to inform itself of factual and legal components that relate foreseeably to a contemplated procedure and to take appropriate measures, in timely fashion, to address them.").

34. Barnidge, supra note 24, at 112 (quoting Pierre-Marie Dupuy, Reviewing the Difficulties of Codification: On Ago's Classification of Obligations of Means and Obligations of Result in Relation to State Responsibility, 10 EUR. J. INT'L L. 371, 379 (1999)).

35. The International Tribunal for the Law of the Sea concluded that "[t]he sponsoring State's obligation "to ensure" is "an obligation to deploy adequate means, to exercise best possible efforts, to do the utmost, to obtain this result." Responsibilities and Obligations Advisory Opinion, supra note 26, ๆ 110 (emphasis added).

36. On the link between the applicable standard of due diligence and the specific risks posed, see the Responsibilities and Obligations Advisory Opinion, supra note 26, 117 ("The standard of due diligence has to be more severe for the riskier activities."). See also the ILC commentary on its Draft Article 3 of the ILC Draft Articles on Prevention of Transboundary Harm from Hazardous Activities, where it stated that "[t]he required degree of care is proportional to the degree of hazard involved." 2001 ILC Report, supra note 22, at 155. 
indisputable that piracy presents serious risks to the international community, as manifested, inter alia, by the unprecedented number of UNSC resolutions adopted on the matter in a relatively short period of time. Accordingly, in the counter-piracy field, the standard of due diligence should be higher than minimum or even reasonable efforts; rather, it should be based on the "best efforts" test. Stated differently, compliance with Article 100 of UNCLOS would require sincere, concerted, and proactive efforts to cooperate internationally in the repression of maritime piracy.

As due diligence is a flexible concept, ${ }^{37}$ assessing its standard requires analysis of not only the particular field of law, but also of the specific obligation within the general duty to cooperate (such as the duty to share information). Additionally, there is a need to consider the facts and circumstances of each case. Indeed, the duty to cooperate prescribed by Article 100 of UNCLOS may entail different actions in different instances, also taking into consideration the tools and resources available to the state in question. Thus, the requirement for "sincere, concerted, and proactive efforts" should not be perceived as defining a uniform, specific set of actions applicable to all states in all situations. This conclusion corresponds to the position expressed by the ILC in its commentary on the duty to cooperate in combating piracy, which stated, "[o]bviously, the State must be allowed a certain latitude as to the measures it should take to this end in any individual case." 38 In addition, and similar to other fields where the due diligence principle has been applied, it is clear that the concept of due diligence implies an obligation of conduct, not of result. ${ }^{39}$

37. See the ILC Commentary to Article 2 of its Draft Articles on the Responsibility of States for Internationally Wrongful Acts, whereby it is mentioned that standards such as due diligence "vary from one context to another for reasons which essentially relate to the object and purpose of the treaty provision or other rule giving rise to the primary obligation." 2001 ILC Report, supra note 22, at 34 . See also Responsibilities and Obligations Advisory Opinion, supra note 26, ๆ 117 ("The content of 'due diligence' obligations may not easily be described in precise terms. Among the factors that make such a description difficult is the fact that 'due diligence' is a variable concept."); Flemme, supra note 31, at 12 ("Flexibility is an essential characteristic of this standard of conduct ....").

38. 1956 ILC Report, supra note 11, at 282.

39. See Report of the International Law Commission to the General Assembly, supra note 27, at 103 ("The obligation of due diligence contained in article 7 sets the threshold for lawful State activity. It is not intended to guarantee that in utilizing an international watercourse significant harm would not occur. It is an obligation of conduct, not an obligation of result."). See also Responsibilities and Obligations Advisory Opinion, supra note 26, ๆ 110 ("The sponsoring State's obligation 'to ensure' is not an obligation to achieve, in each and every 


\section{Article 100 as the Guiding Principle in Identifying the Specific Duties Imposed on States}

A detailed listing and in-depth discussion of all the specific duties required pursuant to Article 100's general obligation to cooperate exceeds the scope of this article. For the purpose of the current discussion, it is submitted that certain duties can be identified based on a holistic interpretation of the piracy section of UNCLOS, which is derived from a joint reading of Article 100 and the substantive provisions of the piracy section. Stated differently, UNCLOS' piracy provisions should be interpreted and implemented in light of the general guideline - namely the duty to cooperate - prescribed by Article 100.

Thus, for example, a key provision under UNCLOS is Article 105, which reads:

On the high seas, or in any other place outside the jurisdiction of any State, every State may seize a pirate ship or aircraft, or a ship or aircraft taken by piracy and under the control of pirates, and arrest the persons and seize the property on board. The courts of the State which carried out the seizure may decide upon the penalties to be imposed, and may also determine the action to be taken with regard to the ships, aircraft or property, subject to the rights of third parties acting in good faith. ${ }^{40}$

Commentators have pointed to the hortatory characteristic of the provision, notably due to the use of the verb "may" throughout this article. ${ }^{41}$ It appears, however, that the use of the verb "may" does not

case, the result that the sponsored contractor complies with the aforementioned obligations. Rather, it is an obligation to deploy adequate means, to exercise best possible efforts, to do the utmost, to obtain this result. To utilize the terminology current in international law, this obligation may be characterized as an obligation 'of conduct' and not 'of result', and as an obligation of 'due diligence.'" (emphasis added)).

40. UNCLOS, supra note 6, art. 105, 1833 U.N.T.S. at 437.

41. GuILFOYLE, supra note 21, at 30-31 ("Under Article 105 of UNCLOS, any state may seize a pirate vessel and its courts may 'decide upon the penalties to be imposed.' This implies a permissive, not mandatory, grant of universal jurisdiction and a choice of means as to how to co-operate to suppress piracy."); Tullio Treves, Piracy and the International Law of the Sea, in MODERN PIRACY: LEgAL CHALlengeS AND RESPONSES 117, 122 (Douglas Guilfoyle ed., 2013) ("The language of article 105 (i.e., 'may') seems to indicate that the exercise of jurisdiction by the seizing state's courts is a possibility, not an obligation, notwithstanding the 'duty' to cooperate in the repression of piracy set out in article 100."); J. Ashley Roach, Countering Piracy Off Somalia: International Law and International Institutions, 104 AM. J. 
imply the discretionary nature of the provision, but is rather meant to indicate that the concrete actions listed under Article 105 are allowed as an exception to the general principles that would otherwise forbid them.

Accordingly, Article 105 permits the seizure of a pirate ship navigating on the high seas as an exception to the general principle of freedom of navigation on the high seas enshrined in UNCLOS, ${ }^{42}$ under which such an intervention would have been considered illegal. Similarly, Article 105 allows every state to exercise criminal jurisdiction over pirates as an exception to the general principle conferring exclusive jurisdiction upon the flag state. ${ }^{43}$

Thus, through the use of the term "may," Article 105 sanctions certain actions that would have otherwise been prohibited under international law. This interpretation of the term "may" also corresponds to the way it is used in other provisions in UNCLOS' piracy section. An example of this is Article 107, which provides that "[a] seizure on account of piracy may be carried out only by warships or military aircraft, or other ships or aircraft clearly marked and identifiable as being on government service and authorized to that effect." 44 As manifested by the title of the provision ("Ships and aircraft which are entitled to seize on account of piracy") ${ }^{45}$ the use of the term "may" in this article indicates which vessels or aircrafts are allowed to conduct the seizure, rather than whether states have the discretion or an obligation to carry out such acts.

Consequently, the use of the term "may" in these provisions does not imply that a state has complete discretion over whether to act. Indeed, this is precisely where the link to Article 100 becomes relevant. If a state is in a position to seize a pirate ship or take other

INT'L L. 397, 403 (2010) ("[Article 105], like all of the piracy provisions save Article 100, is discretionary-'may' . . .").

42. UNCLOS, supra note 6, art. 87(1)(a), 1833 U.N.T.S. at 432.

43. See id. art. 92(1), at 433 ("Ships shall sail under the flag of one State only and, save in exceptional cases expressly provided for in international treaties or in this Convention, shall be subject to its exclusive jurisdiction on the high seas."). See also M/V Saiga (No. 2) (St. Vincent v. Guinea), Case No. 2, Judgment of July 1, 1999, 3 ITLOS Rep. 10, 48 ("[T] he ship, every thing on it, and every person involved or interested in its operations are treated as an entity linked to the flag State."); Medvedyev v. France, Judgment of Mar. 29, 2010, para. 85 (Eur. Ct. H.R. 2010), http://hudoc.echr.coe.int/webservices/content/ pdf/001-97979?TID=ufyxypubrf (mentioning the principle of universal jurisdiction over piracy acts as an exception to the rule of the exclusive jurisdiction of the flag state); TANAKA, supra note 7 , at $152-55$.

44. UNCLOS, supra note 6, art. 107, 1833 U.N.T.S. at 437 (emphasis added).

45. Id. (emphasis added). 
actions sanctioned by Article 105, and it nonetheless chooses not to act, for example, due to reasons of political convenience, it can certainly be argued that this state did not fulfill its obligations under international law. More specifically, it can be argued that the state failed to fulfill its obligation to cooperate in the suppression of piracy under Article $100 .{ }^{46}$ To be clear, the combination of Articles 100 and 105 does not create an obligation to seize a pirate ship under all circumstances. Yet the state concerned should present a sound explanation for its lack of action in light of the presumption of cooperation and the due diligence standard created by Article 100. To that end, an attempt to rely on the term "may" in Article 105 as allegedly pointing to the hortatory nature of the provision does not appear to be convincing and might put into question the state's good faith in raising such an argument.

Article 100 can further serve as a benchmark to construe the piracy provisions in case a doubt arises on the appropriate interpretation. One example already mentioned in the literature on piracy concerns the practice of naval forces operating off the coast of Somalia to hand over suspected pirates to regional states such as Kenya to face trial. Article 105 provides neither explicit authority to do so, nor does it expressly prohibit such cooperation between the arresting state and the prosecuting one. In response to the argument that in accordance with Article 105 only the arresting state has jurisdiction to try the pirate ${ }^{47}$ it has been correctly contended that such an argument "is inconsistent with the strong duty of cooperation

46. A similar position (though without explicitly referring to a violation of a duty under international law) can be found in Professor Wolfrum's discussion of Article 107 of UNCLOS, where he stated that "[i]t has to be acknowledged that the central provision, namely article 107 of the Convention, is worded as an option for States to take up rather than as an obligation incumbent upon them. However, States are under an obligation to cooperate in the repression of piracy (article 100 of the Convention). Reading article 100 and 107 of the Convention together, it can be argued that States may not lightly decline to intervene against acts of piracy." Wolfrum, supra note 17, at 3-4. A different position was expressed by John Kavanagh, who argued that "a state's non-compliance with the provision [Article 100] would not constitute a breach of international law. In other words, a state could avoid the prosecution of a pirate who is within its jurisdiction or avoid the enactment of legislation to provide for prosecution." John Kavanagh, The Law of Contemporary Sea Piracy, 1999 AustL. InT'L L.J. 127, 14041 (referring to Barry H. Dubner, The Law of International Sea PIRACY 108 (1980)).

47. See Eugene Kontorovich, United States v. Shi. 525 F.3d 709, Cert. Denied, 129 S.Ct. 324 (2008) United States Court of Appeals for the Ninth Circuit, April 24, 2008, 103 AM. J. InT'L L. 734, 739 (2009) (noting that transfer might be illegal under UNCLOS because it only allows capturing nations to prosecute pirates). 
in the international law of piracy articulated by Article 100. The practice of states reflected in their arrangements with Kenya indicates that they believe cooperation includes transfers ashore to third states for trial and that they are permitted under international law." ${ }^{48}$

Finally, Article 100 can also be invoked to support counter-piracy initiatives in accordance with states' national legislation. For example, it has been reported that the Netherlands uses this provision as the legal basis for its authorization of Vessel Protection Detachments (VPDs) on Dutch ships under its Constitution. ${ }^{49}$

\section{The Duty to Share Information as a Specific Obligation Under the General Duty to Cooperate}

The concrete measures to be applied by states as part of their general duty to cooperate are determined based on the characteristics of the particular threat and the circumstances of each case. Whatever the specific measures are, however, there should be little doubt that

48. Roach, supra note 41, at 404 (countering Eugene Kontorovich's position that expresses a more restricted reading of Article 105). A conclusion similar to that of Roach - though without basing it on Article 100-was presented by Lawrence Azubuike, who also countered Kontorovich's position by arguing that "[n]othing on the face of the Article [105] makes the jurisdiction exclusive to the arresting State." Lawrence Azubuike, International Law Regime Against Piracy, 15 AnN. SurV. INT'L \& COMP. L. 43, 54-55 (2009). An opinion similar to that of Kontorovich was presented by Joseph M. Isanga. To support their position, both Kontorovich and Isanga pointed to the commentary to Article 43 of the ILC Articles Concerning the Law of the Sea (which is the equivalent to Article 105 of UNCLOS). See Joseph M. Isanga, Countering Persistent Contemporary Sea Piracy: Expanding Jurisdictional Regimes, 59 AM. U. L. REv. 1267, 1279 (2010) (finding that UNCLOS does not extend universal jurisdiction to cases involving extradition). The ILC commentary reads: "This article gives any State the right to seize pirate ships (and ships seized by pirates) and to have them adjudicated upon by its courts. This right cannot be exercised at a place under the jurisdiction of another State." 1956 ILC Report, supra note 11, at 283. As indicated, this author supports the position expressed by Roach and Azubuike in light of the importance attached to international cooperation in combating piracy as provided for by Article 100 of UNCLOS. A conclusion supporting broad interpretation of Article 105 (and the rest of the piracy provisions) can also be deduced from the object and purpose of the piracy section of UNCLOS, namely the common interest of the international community in ensuring the freedom of navigation and the safety of persons and property upon the high seas.

49. See Clive R. Symmons, Embarking Vessel Protection Detachments and Private Armed Guards on Board Commercial Vessels: International Legal Consequences and Problems Under the Law of the Sea, 51 MIL. L. \& L. WAR REV. 21, 33 n.51 (2012). 
information exchange is vital to ensure successful international cooperation in counter-piracy operations.

Indeed, the duty to share information can be identified as a particular obligation within the general duty to cooperate. This conclusion is supported by relevant international instruments. For example, the SUA Convention provides that "States Parties shall co-operate in the prevention of the offences set forth in article 3, particularly by ... exchanging information in accordance with their national law .....".50

As explained by Justice Tuerk in reference to that provision: "there is a duty for States Parties that have a reason to believe that an offense set forth in the [SUA] Convention will be committed to furnish as promptly as possible any relevant information to those States having established jurisdiction over such offenses." ${ }^{\text {51 }}$

In addition, the UNSC resolutions related to the suppression of piracy and armed robbery at sea also urge all states to share information on acts related to piracy and armed robbery at sea..$^{52}$ The U.N. General Assembly has also emphasized the importance of information sharing as part of international cooperation in addressing the problem of piracy. ${ }^{53}$

On the regional level, the need for information sharing as a means of promoting cooperation in the suppression of piracy was a prime motivator for Asian states in adopting the Regional Cooperation Agreement on Combating Piracy and Armed Robbery Against Ships

50. SUA Convention, supra note 3, art. 13.1(b), 1678 U.N.T.S. at 230-31.

51. Tuerk, supra note 1 , at 349 .

52. See S.C. Res. 1816, supra note 4, 3 ("Urg[ing] all States to cooperate with each other ... and share information about, acts of piracy and armed robbery in the territorial waters and on the high seas off the coast of Somalia . . ."). The UNSC reiterated the importance of sharing information in other resolutions as well. See, e.g., S.C. Res. 1846, para. 7, U.N. Doc. S/RES/1846 (Dec. 2, 2008); S.C. Res. 1976, para. 19, U.N. Doc. S/RES/1976 (Apr. 11, 2011). In more recent Resolutions, the UNSC explicitly highlighted the importance of sharing evidence and information among states and international organizations for anti-piracy law enforcement purposes including with regard to the key figures of the criminal networks involved in piracy. See, e.g., S.C. Res. 2077, supra note 2, ๆ 9.

53. See G.A. Res. 63/111, supra note 5, đ 61 ("[The General Assembly] $[r]$ ecognizes the crucial role of international cooperation at the global, regional, subregional and bilateral levels in combating, in accordance with international law, threats to maritime security, including piracy, armed robbery at sea . . . through . . . the enhanced sharing of information among States relevant to the detection, prevention and suppression of such threats . . . ."). See also G.A. Res. 66/231, supra note 5, ๆ 81; G.A. Res. 67/78, supra note 5, ๆ 88. 
in Asia (ReCAAP). ${ }^{54} \mathrm{~A}$ key feature of ReCAAP is the creation of an information sharing center, based in Singapore, whose role is to undertake the collection, collation, and analysis of information received from state parties and to ensure a flow of information between them. ${ }^{55}$ Similarly, the more recent sub-regional Codes of Conduct, adopted in 2009 in Djibouti ${ }^{56}$ and in 2013 in Cameroon, ${ }^{57}$ both inspired by ReCAAP ${ }^{58}$ each provide that cooperation among the state parties shall include "sharing and reporting relevant information." "59 The Codes of Conduct further provide for detailed obligations related to information sharing, such as the need to designate a national focal point to facilitate coordinated, timely, and effective flow of information. ${ }^{60}$

The duty to exchange information related to the prevention and suppression of maritime piracy may also derive independently from the abovementioned principle of due diligence. This concept entails, inter alia, that states have a responsibility to forewarn other countries about potential threats by communicating relevant information and updating international police databases in a systematic and comprehensive fashion. ${ }^{61}$ The "responsibility to forewarn" is not a new

54. Natalie Klein, Maritime Security and the Law of the Sea 242 (Vaughan Lowe et al. eds., 2011).

55. Regional Cooperation Agreement on Combating Piracy and Armed Robbery Against Ships in Asia art. 7, Nov. 11, 2004, 2398 U.N.T.S. 199 (entered into force Sept. 4, 2006); KLEIN, supra note 54, at 242-43.

56. Int'l Maritime Org. [IMO], Code of Conduct Concerning the Repression of Piracy and Armed Robbery Against Ships in the Western Indian Ocean and the Gulf of Aden, Djibouti Meeting Res. 1 (Jan. 29, 2009) [hereinafter Djibouti Code of Conduct], available at http://www.imo. org/OurWork/Security/PIU/Documents/DCoC\%20English.pdf.

57. Economic Community of West African States [ECOWAS] et al., Code of Conduct Concerning the Repression of Piracy, Armed Robbery Against Ships, and Illicit Maritime Activity in West and Central Africa (June 25, 2013) [hereinafter Gulf of Guinea Code of Conduct], available at http://www.ecowas.int/publications/en/maritime_security/code_of_co nduct.pdf.

58. See Djibouti Code of Conduct, supra note 56, pmbl. The Gulf of Guinea Code of Conduct was in turn, inspired by the Djibouti Code of Conduct. See Gulf of Guinea Code of Conduct, supra note 57, pmbl.

59. Djibouti Code of Conduct, supra note 56, art. 2(1); Gulf of Guinea Code of Conduct, supra note 57, art. 2(1).

60. See Djbouti Code of Conduct, supra note 56, art. 8 ("Coordination and Information Sharing"); see Gulf of Guinea Code of Conduct, supra note 57 , art 11 (same).

61. See Rutsel Silvestre J. Martha, The Legal Foundations of INTERPOL 26-28 (2010); see also Ronald K. Nobel, INTERPOL Secretary General, Prosecuting Terrorism: The Global Challenge, Keynote Address Organized by NYU Center on Law \& Security (June 4, 
notion under international law. For example, in the Corfu Channel case, the International Court of Justice pointed to the duty of states to notify and warn countries of an imminent danger based on certain general and well-recognized principles such as elementary considerations of humanity. ${ }^{62}$

With the Corfu Channel case in mind, ${ }^{63}$ the obligation to forewarn was introduced into UNCLOS, where it is provided in Article 24(2) that "[t]he coastal State shall give appropriate publicity to any danger to navigation, of which it has knowledge, within its territorial sea." ${ }^{\prime 64}$ It would be reasonable to contend that activities of a piratical nature pose a "danger to navigation" within the meaning of Article 24(2), thereby requiring the coastal state to warn other states of such known activity in its territorial waters. Beyond the territorial sea, the duty to forewarn is a corollary obligation of the duty to cooperate enshrined in Article 100 of UNCLOS, and by other relevant instruments, such as the SUA Convention and the abovementioned UNSC resolutions.

\section{The Nature of Cooperation: A Call for Holistic INTER-DISCIPLINARY COOPERATION}

Having established the existence of a general duty to cooperate and to share information, consideration should be given to the nature of the required cooperation in combating maritime piracy. Specifically, this article proposes a departure from the traditional concepts related to crime prevention in favor of adopting a holistic, inter-disciplinary paradigm for cooperation.

2004), available at http://www.interpol.int/Public/ICPO/speeches/ SG20040604.asp ("Countries have a responsibility to forewarn other countries about individuals that present a potential threat. . . . The practical implication is that countries have to ensure that they communicate all potentially relevant information to other countries and update international police databases in a systematic and comprehensive fashion."). In the context of combating terrorism, the duty to forewarn of imminent threats was underscored by the UNSC in Resolution 1373, where the USNC, acting under Chapter VII of the U.N. Charter, decided that all states shall "[t]ake the necessary steps to prevent the commission of terrorist acts, including by provision of early warning to other States by exchange of information." S.C. Res. 1373, para. 2(b), U.N. Doc. S/RES/1373 (Sept. 28, 2001).

62. Corfu Channel (U.K. v. Alb.), Judgment, 1949 I.C.J. 4, 22 (Apr. 9); MARTHA, supra note 61 , at 27.

63. See TANAKA, supra note 7, at 96 (stating that Article 24(2) of UNCLOS incorporated the dictum from the Corfu Channel case regarding the duty to warn).

64. UNCLOS, supra note 6, art. 24(2), 1833 U.N.T.S. at 407. 
Traditionally, governmental authorities and international entities operating in different fields have carried out their missions virtually independently of each other: the police engage in purely police work, the military engage in purely military operations, and so on. In addition, the level of cooperation between such bodies and the private sector has frequently been insignificant, if not practically non-existent.

This traditional paradigm may work effectively when combating classic forms of crime such as land-based murder, robbery, and theft. Nonetheless, the challenges that have accompanied relatively new forms of crime such as terrorism, or the "resurrection" of old crimes such as maritime piracy, have highlighted the shortcomings of this conventional approach.

This shift in the risks posed to our societies necessitates adjustment on two levels. First, substantive changes are necessary, namely with regard to the type of tasks carried out by each actor. Thus, for example, military forces might be requested to engage in activities of a law enforcement nature, and police forces might be asked to investigate illegal activities which, in the past, have not been considered "typical" ordinary law crimes in the strict sense of that term.

Second, and stemming also from these substantive changes, institutional - or, more precisely, inter-institutional-adjustments are required. Concretely, there is a need to involve all relevant actors in this process - hence, the call for a holistic approach - and to establish cooperation among agencies and institutions whose role, mandate, and general activities may often be significantly different from one another. Enabling and coordinating the interaction between such bodies, namely inter-disciplinary cooperation, is not only desirable, but is in fact imperative.

The "holistic inter-disciplinary cooperation" paradigm is of particular relevance in the field of maritime piracy. Despite the fact that piracy is a classic crime, its geographic location requires the involvement of naval forces. In addition, the shipping industry is often in possession of valuable information that can be used for criminal investigations and prosecutions. Thus, there is clearly a need to establish collaboration among navies, law enforcement agencies, and the private sector. As will be discussed in the next section, such collaboration is not without challenges, yet it remains essential to successful counter-piracy undertakings.

\section{Challenges in Sharing Information in the Fight Against Piracy}

Sharing relevant information among states and international organizations is vital for combating piracy and should therefore be applied as the general standard procedure. Information exchange nonetheless faces a number of difficulties that will be addressed below. 


\section{A. Scope of the Duty to Share Information and the "National Security" Exception}

Frequently, the international instruments applicable to the suppression of piracy do not shed much light on the precise scope of the duty to share information. As already noted in this article, the duty to share information in reference to piracy is not explicitly mentioned in Article 100 of UNCLOS (or elsewhere in the piracy section). ${ }^{65}$ In the SUA Convention, the need to share information is mentioned, yet without further details. ${ }^{66}$

Consequently, states are left to decide what precise information should be shared, how it is to be transmitted, and when it is to be delivered. ${ }^{67}$ Moreover, even when more detail on the duty to share information is provided, restrictions are often imposed due to national security, sovereignty, or commercial confidentiality concerns. ${ }^{68}$ Such restrictions are found in the SUA Convention (exchange of information "in accordance with national law"69), as well as in Article 302 of UNCLOS, a general provision concerning the disclosure of information: "[N] othing in this Convention shall be deemed to require a State Party, in the fulfilment of its obligations under this Convention, to supply information the disclosure of which is contrary to the essential interests of its security." 70

These restrictions - in particular, those based on the "national security" argument - can be used by states to justify their decision not to share information. ${ }^{71}$ Nonetheless, it is submitted that the implementation of laws and regulations that prevent or restrict the exchange of information should be done only as an exception to the general obligation to share information deriving from Article 100 and the due diligence principle. Thus, if a state possesses relevant data,

65. Compare $i d$. art. 100 , at 436 , with $i d$. art. 200, at 480 (according to which states shall cooperate through the exchange of information and data acquired about pollution of the marine environment).

66. See SUA Convention, supra note 3, art. 13(b), 1678 U.N.T.S. at 230-31 ("State Parties shall co-operate in the prevention of the offences set forth in article 3, particularly by . . . exchanging information in accordance with their national law, and co-ordinating administrative and other measures taken as appropriate to prevent the commission of offences set forth in article 3.").

67. See KLEIN, supra note 54, at 255 (finding that in the law enforcement context, states often agree to no more than a duty to cooperate, leaving the specifics of the duty to states' discretion).

68. Id. at $255-56$.

69. SUA Convention, supra note 3, art. 13(b), 1678 U.N.T.S. at 230-31.

70. UNCLOS, supra note 6, art. 302, 1833 U.N.T.S. at 516.

71. See KLEIN, supra note 54, at 254 (mentioning the problem of national security interests trumping international security interests). 
and it neglects - or even refuses - to share it, it carries the burden of justifying such a position.

This approach is grounded in the wording of provisions such as the abovementioned Article 302 of UNCLOS, which allows non-disclosure of information only for purposes of protecting "essential interests of [state] security." ${ }^{2}$ It is further based on the fundamental principle under international law requiring states to fulfill their obligations in good faith. Indeed, if, as a matter of policy, a state refrains from sharing information related to the prevention and suppression of maritime piracy, it can hardly be argued that it fulfills its obligation to cooperate in good faith.

This conclusion is further supported by the nature of piracy as, in essence, an ordinary law crime. Accordingly, the type of information whose sharing is of importance for the purpose of combating maritime piracy would typically be that which is exchanged as a standard procedure among law enforcement authorities when countering crime: identification of suspects, modus operandi, etc. Thus, in general, the sharing of such information between the entities involved in counter-piracy operations (whether the navies or law enforcement agencies) is unlikely to compromise national security. It should therefore not be surprising that at least among law enforcement agencies and based on INTERPOL's practice following the creation of its Global Maritime Piracy Database, ${ }^{73}$ in the domain of maritime piracy, very few restrictions have been imposed by INTERPOL's member countries on information exchanged via the INTERPOL information system. ${ }^{74}$ As described in the next section, however, the

72. UNCLOS, supra note 6, art. 302, 1833 U.N.T.S. at 516 (emphasis added).

73. INTERPOL's Global Piracy Database was created in 2011 and was mentioned in UNSC Resolutions such as Resolution 2020. S.C. Res. 2020, para. 19, U.N. Doc. S/RES/2020 (Nov. 22, 2011) ("[The Security Council] [c]ommends INTERPOL for the creation of a global piracy database designed to consolidate information about piracy off the coast of Somalia and facilitate the development of actionable analysis for law enforcement, and urges all States to share such information with INTERPOL for use in the database, through appropriate channels."). As of July 2013, the database contains information on piracy events, pirates' weapons, bank accounts, suspected financiers, negotiators, and more. For further information on the database, see Pierre St. Hilaire, Somali Piracy: Following the Paper Trail 6-7 n.4 (June 2012) (on file with the United Arab Emirates Counter Piracy Conference), available at http://www.counterpiracy.ae/2012-briefing-papers.

74. In accordance with INTERPOL's Rules on the Processing of Data (RPD), the source of data that circulated via INTERPOL's channels retains control over its data. INTERPOL, Rules on the Processing of Data, art. 7(1), available at http://www.coe.int/t/dghl/standardsetting/ dataprotection/tpd_documents/R\%C3\%A8glement\%20INTERPOL_en. pdf. This includes, inter alia, the right to impose restrictions on the 
flow of information between the navies and law enforcement entities is not without difficulties.

\section{B. Challenges Deriving from the Nature of the Crime and the Entities Involved in Counter-Piracy Operations}

1. Navies carrying out law enforcement activities

Since piracy takes place on the high seas, and often very far from the shore, combating piratical acts requires more than the typical police-prosecution cooperation, which is predominant in land-based ordinary law crimes such as theft or robbery. Notably, it calls for the involvement of navies as the front-line entities that both prevent attacks and gather relevant information to facilitate prosecution. In fact, in such operations, the navies exercise activities of a law enforcement nature. This unique feature in combating maritime piracy creates certain problems including those related to information exchange.

The lead role taken by navies in combating piracy has also led the international community to overlook the role of law enforcement organizations and agencies, particularly during the early stages of combating piracy off the coast of Somalia. Thus, despite the fact that by the end of 2008 a shift towards a law enforcement paradigm was already underway, ${ }^{75}$ it was not until late November 2010 that the UNSC - already in its eleventh resolution related to piracy off the coast of Somalia ${ }^{76}$ - made a clear reference to organizations such as INTERPOL and Europol operating in the counter-piracy field.

In Resolution 1950, the UNSC underlined the importance of continuing to enhance the collection, preservation, and transmission of evidence of acts of piracy to competent authorities; welcomed the

access or the use of such data by other users of the system, namely by other countries or international entities. $I d$. arts. 7(1), 58.

75. Douglas Guilfoyle, Piracy off Somalia and Counter-Piracy Efforts, in Modern PIRACy: Legal Challenges And ResPonses, supra note 41, 35, $50-51$

76. The first UNSC Resolution making a reference to the threats posed by maritime piracy off the coast of Somalia was UNSC Resolution 1676. See S.C. Res. 1676, U.N. Doc. S/RES/1676 (May 10, 2006). The UNSC reiterated its concerns over piratical incidents in Resolution 1772. See S.C. Res. 1772, U.N. Doc. S/RES/1772 (Aug. 20, 2007); S.C. Res. 1801, U.N. Doc. S/RES/1801 (Feb. 20, 2008). The first time the UNSC addressed piracy off the coast of Somalia as the primary subject matter of a resolution was in June 2008, when it adopted Resolution 1816. See S.C. Res. 1816, supra note 4. That resolution was followed by the following resolutions adopted by November 2010: S.C. Res 1838, U.N. Doc. S/RES/1838 (Oct. 7, 2008); S.C. Res. 1844, U.N. Doc. S/RES/1844 (Nov. 20, 2008); S.C. Res. 1846, supra note 52; S.C. Res. 1851, U.N. Doc. S/RES/1851 (Dec. 16, 2008), S.C. Res. 1897, U.N. Doc. S/RES/1897 (Nov. 30, 2009); and S.C. Res. 1918, supra note 2. 
ongoing work of the International Maritime Organization (IMO), INTERPOL, and industry groups to develop guidance to seafarers on preservation of crime scenes following acts of piracy; and urged states, in cooperation with INTERPOL and Europol, to further investigate international criminal networks involved in piracy off the coast of Somalia, including those responsible for illicit financing and facilitation. ${ }^{77}$ This rather late inclusion of the law enforcement angle in UNSC resolutions (and elsewhere) was particularly surprising, given that the guidelines for involving police forces in combating maritime piracy had already been put in place when the situation off the coast of Somalia began to deteriorate. ${ }^{78}$

By not considering the potential in engaging the law enforcement community, a number of difficulties have emerged, particularly with regard to facilitating the prosecution of pirates, a task that typically falls within the expertise of law enforcement agencies. Naval forces do not necessarily have the tools or the expertise to gather and preserve the relevant evidence necessary for criminal proceedings. ${ }^{79}$ In addition, they generally do not have criminal databases where important data such as personal information on suspects, fingerprints, and DNA can be stored and compared with existing data. Such expertise and tools are at the core of law enforcement activities and international police cooperation. The relative lack of involvement of the police in those early stages therefore created a gap, or a "missing link," between the navies operating off the coast of Somalia and the prosecution services.

The growing recognition of the need to engage all relevant actors, including the law enforcement community, as part of the holistic interdisciplinary paradigm, led to welcome changes in the mindset that guided the international community in the early stages of combating piracy off the coast of Somalia.

Thus, in addition to the abovementioned UNSC Resolution 1950, three noteworthy examples of the positive shift in approach are found in the following instruments. First, in UNSC Resolution 1976, the

77. See S.C. Res. 1950, para. 16, U.N. Doc. S/RES/1950 (Nov. 23, 2010).

78. See, e.g., Int'l Maritime Org. [IMO], Code of Practice for the Investigation of the Crimes of Piracy and Armed Robbery Against Ships, IMO Assemb. Res. A. 922 (22) (Nov. 29, 2001). Among the points included in that Code were the following: involve relevant organizations (e.g., INTERPOL) at an early stage; evidence accumulated from different cases may create opportunities to identify offenders; appropriate databases should be searched; and contacting INTERPOL for information on the offenders (e.g., prior convictions) is important. $I d$. $\Upsilon$ \ 5.6, 7.16.

79. See Håkan Friman \& Jens Lindborg, Initiating Criminal Proceedings with Military Force: Some Legal Aspects of Policing Somali Pirates by Navies, in Modern Piracy: Legal Challenges And Responses, supra note 41 , at 172,195 . 
UNSC, acting under Chapter VII of the U.N. Charter: (1) invited states, individually or in cooperation with regional organizations, UNODC, and INTERPOL, to examine domestic procedures for the preservation of evidence and assist Somalia and other states in the region in strengthening their counter-piracy law enforcement capacities; (2) underlined the importance of continuing to enhance the collection, preservation, and transmission of evidence to competent authorities; and (3) urged states and international organizations to share evidence and information for anti-piracy law enforcement purposes with a view to ensuring effective prosecution. ${ }^{80}$ UNSC Resolution 2020 further highlighted the importance of sharing information with INTERPOL and Europol, including for the purposes of investigating those responsible for illicit financing and facilitation. ${ }^{81}$

The second example is the amendment to the 2008 European Union Council Decision on Operation Atalanta, which is the European Union military operation off the coast of Somalia. The amended framework explicitly instructs Operation Atalanta to: (1) collect data including characteristics likely to assist in identification of piracy suspects such as fingerprints; and (2) circulate, via INTERPOL's channels, and check against INTERPOL's databases, personal data concerning suspects, including fingerprints and other identifiers (e.g., name, DOB, etc.). ${ }^{82}$

A third example concerns the updates introduced in the fourth version of the Best Management Practices for Protection Against Somalia Based Piracy (BMP4). In the BMP4, produced and supported by a number of prominent players in the civil industry and naval forces, a specific chapter was added on cooperation with law enforcement authorities. ${ }^{83}$

These three examples illustrate a positive shift in the strategic view of counter-piracy undertakings. Yet, certain complexities related to the exchange of information between navies and law enforcement entities had to be addressed. First, as a matter of normal procedure, navies tend to designate the data they collect as "classified information." This poses serious impediments with regard to the use of such data for the purpose of prosecution on the national level, as well as in the context of international collaboration with entities (i.e., countries or international organizations) that generally do not

80. S.C. Res. 1976, supra note 52, ๆ $16,18,19$.

81. S.C. Res. 2020, supra note 73, ฯ 18.

82. See Council Decision 2010/766/CFSP, art. 1, 2010 O.J. (L 327) 49, 50 (EU).

83. BMP 4: Best Management Practices for Protection Against SOMALI BASED PIRACY, § 12 (2011) [hereinafter BMP4], available at http://www.mschoa.org/docs/public-documents/bmp4_low_res_sep_5 2011.pdf (referring to the section titled "Post Incident Reporting"). 
have access to classified information. As an example from INTERPOL's practice, this issue had to be addressed during the discussions that led to the conclusion of a pilot agreement on information sharing between NATO and INTERPOL. ${ }^{84}$

To address this concern, it is submitted that while the implementation of classified information rules is justified in the operations of navies during wartime or in preparation for military activities, a different approach should govern the operations of naval forces when carrying out missions of a law enforcement nature such as counter-piracy activities. Thus, applying standard navy classification procedures in this context, and consequently withholding from law-enforcement agencies important information such as fingerprints of suspected pirates, can hardly serve the original purpose of classified information. Further, it does not correspond to the general obligation to share information in combating maritime piracy. Piracy-related information either should not be designated as "classified information" in the first place, or it should be declassified as standard procedure.

Sharing information in the other direction, specifically from law enforcement entities to the navies, also posed certain challenges. For example, in the context of INTERPOL's work, a question arose whether INTERPOL may cooperate with navies considering Article 3 of its Constitution, according to which "[i]t is strictly forbidden for the Organization to undertake any intervention or activities of a political, military, religious or racial character." ${ }^{85}$ A plain reading of this provision could have led to the conclusion that INTERPOL must not share any information with the navies or organizations that operate off the coast of Somalia, such as NATO. INTERPOL nonetheless concluded that as long as the purpose and nature of the collaboration is confined to promoting international police cooperation, Article 3 does not prevent it from doing so. ${ }^{86}$ Based on

84. See INTERPOL and NATO Cooperation Set to Boost Global Efforts Against Maritime Piracy, INTERPOL (Oct. 6, 2012), http://www.interpol.int/en/Internet/News-and-media/News-mediareleases/2012/N20121006. INTERPOL also provided specialized training for the crew of naval vessels ahead of their deployment under the NATO anti-piracy mission, Operation Ocean Shield. See INTERPOL Training Supports NATO Anti-Piracy Mission, INTERPOL (Oct. 12, 2013), http://www.interpol.int/en/News-and-media/News-media-releases/ 2013/N20131012/.

85. INTERPOL, Constit. art. 3 (June 13, 1956), available at http://www. interpol.int/About-INTERPOL/Legal-materials/The-Constitution.

86. For further discussion of Article 3 of INTERPOL's Constitution and specifically on the application of the "purpose and nature" test in the field of maritime piracy, see Yaron Gottlieb, Article 3 of INTERPOLS's Constitution: Balancing International Police Cooperation with the Prohibition on Engaging in Political, Military, Religious, or Racial Activities, 23 FLA. J. INT'L L. 135, 183-84 (2011). 
this functional interpretation of Article 3, which permits in principle the flow of data from INTERPOL to the naval forces ${ }^{87}$ INTERPOL shared information with the navies deployed in the Indian Ocean, such as a photo album of suspected pirates. The information contained in the photo album, gathered by INTERPOL from its member countries, can assist the navies in identifying Somali pirates, and it can potentially support a decision by the navy to detain suspects pending further investigations. ${ }^{88}$

\section{Interaction with the shipping industry}

Another important player in the fight against maritime piracy is the private sector, including ship owners, operators, and insurance companies. ${ }^{89}$ The role of shipping companies is particularly important in the field of sharing information, since they have access to crucial data and are also in a position to enable the collection of evidence by the police.

Nonetheless, cooperation and information sharing between the private sector and law enforcement bodies has not been seamless. First, the shipping industry had to be sensitized to the importance of post-incident reporting, preserving the crime scene for the purpose of evidence gathering, and facilitating interviews with the crew of hijacked ships..$^{90}$ Thus, despite existing guidelines, it was not uncommon to have cases where ships were thoroughly cleaned by their crews immediately upon their release by the pirates and prior to any law enforcement engagement, thereby destroying any potential

87. A decision on sharing such information must also be taken in conformity with all INTERPOL's rules, notably with the RPD.

88. See Greece to Prosecute First Maritime Piracy Case with Evidence Gathered by INTERPOL Team, INTERPOL (Dec. 12, 2012), http://www.interpol.int/fr/News-and-media/News-media-releases/2012/ PR098.

89. St. Hilaire, supra note 73 , at $2-3$.

90. BMP4, supra note 83, § 12. See also IMO, supra note 78, ๆ 6.7-6.9 (discussing the securing of evidence); S.C. Res. 2077, supra note 2, pmbl. (underlining "the importance of continuing to enhance the collection, preservation and transmission to competent authorities of evidence of acts of piracy and armed robbery at sea off the coast of Somalia"). The UNSC further welcomed "the ongoing work of the IMO, INTERPOL, and industry groups to develop guidance to seafarers on preservation of crime scenes following acts of piracy, and noting the importance for the successful prosecution of acts of piracy of enabling seafarers to give evidence in criminal proceedings." S.C. Res. 2077, supra, note 2. In that resolution, the UNSC further urged states "to make their citizens and vessels available for forensic investigation as appropriate at the first suitable port of call immediately following an act or attempted act of piracy or armed robbery at sea or release from captivity." Id. ๆ 29. 
crime scene investigation. Direct collaboration with shipping companies proved that this hurdle can be overcome. For example, following the release of the hijacked oil tanker Irene SL in April 2011, INTERPOL immediately dispatched to the vessel an Incident Response Team (IRT). The IRT, supported by the South African Police Service, and in coordination with European Union Naval Force (EU NAVFOR) and INTERTANKO, gathered evidence which later served to assist Greece in its first prosecution of a piracy case. ${ }^{91}$ This successful deployment paved the way for similar INTERPOL-led IRTs, where crime scene evidence was collected and hostages were debriefed following their release. ${ }^{92}$ In July 2013, INTERPOL also carried out its first IRT mission on a ship that was attacked by pirates operating in the Gulf of Guinea.

An additional difficulty concerns the trust gap between the shipping industry and other entities, notably governmental authorities such as navies and law enforcement agencies. This obstacle to information sharing has been particularly relevant in reference to ransom payments. Typically, negotiations over ransom payments are conducted directly between the pirates or their representatives and the shipping company or its representatives..$^{93}$ In the context of such negotiations, information of relevance for future investigation and prosecution might be obtained, including names of negotiators and phone numbers. Frequently, however, the shipping company concerned has been hesitant to share such information with governmental authorities. This may derive from an assessment that the information may be business sensitive; an assumption that sharing information might frustrate the on-going (or future) negotiations; or even a fear of potential criminal proceedings against the representatives of the shipping industry in countries where paying ransom to pirates is criminalized. Overcoming this trust gap enabled the population of international criminal databases with relevant information to be used for future analytical reports and potential prosecution of pirates' kingpins. To maintain the positive momentum, it is important that the private sector receive feedback on the information it provides to governmental authorities so that it can appreciate the effects of its collaboration.

91. See Greece to Prosecute First Maritime Piracy Case with Evidence Gathered by INTERPOL Team, supra note 88.

92. As of July 2013, INTERPOL has carried out six more IRTs following the release of ships hijacked by Somali pirates.

93. See Vivienne Walt, Why the Somali Pirates Keep Getting Their Ransoms, TIME (Apr. 20, 2009), http://content.time.com/time/world/ article/0,8599,1892366,00.html (noting how shipping companies routinely conduct the negotiations with pirates and pay ransom sums). 


\section{The Proliferation of Information Networks and Its Discontents}

One of the marked developments on the international level in recent decades is the proliferation of non-synchronized networks, which contribute to the creation of a "new world order." 94 This phenomenon was attributed to three core factors: technological innovation that enables information exchange, the expansion of domestic regulation, and the rise of globalization. ${ }^{95}$ The international response to the surge in piracy incidents off the coast of Somalia and in the Gulf of Guinea exemplifies the scope of this phenomenon. Within a relatively short period of time, new institutions and structures were promptly created to address the new threats and specifically to facilitate the exchange of information. These included, for example, the creation of an operational network under the auspices of "The Shared Awareness and Deconfliction" (SHADE) initiative $^{96}$ and the establishment of three information sharing centers under the Djibouti Code of Conduct. ${ }^{97}$

The proliferation of new information sharing networks raises a number of challenges. First, it creates confusion as to which network should be used and which entity should be approached in a particular case. This problem is even more acute where the possessor of the information, who wants to share it, is not accustomed to communicating with entities from other disciplines-for example where a private shipping company wishes to communicate information to the navy or the police.

In addition, the abundance of networks frequently leads to two extreme and problematic situations related to the circulation of an item of information. One extreme is a case where an item is circulated simultaneously in different networks, and consequently, users that are connected to these networks receive the exact same item multiple times. This duplication (or multiplication) of communication burdens the information system and its users, and it wastes valuable resources.

94. Anne-Marie Slaughter, A New World Order 15 (2004).

95. Kal Raustiala, The Architecture of International Cooperation: Transgovernmental Networks and the Future of International Law, 43 VA. J. INT'L L. 1, 16 (2002).

96. The SHADE initiative began in 2008 as a mechanism of meetings aimed at coordinating and de-conflicting activities between the countries and coalitions involved in military counter-piracy operations in the Gulf of Aden and the western Indian Ocean. See generally Shared Awareness and Deconfliction (SHADE), OCEANS BEYOND PIRACY, http:// oceansbeyondpiracy.org/matrix/shared-awareness-and-deconflictionshade (last visited Mar. 5, 2014) (containing more information on SHADE).

97. See Djibouti Code of Conduct, supra 56, art. 8(1) (describing the centers established in Kenya, Tanzania, and Yemen). 
The opposite scenario is also quite common and is potentially even riskier: it concerns the situation where networks operate in "close circuit" and without coordination. This leads to valuable items of information being lost due to the silo-style structure of the networks. Such a situation can have harsh consequences where an item of information circulated in one network is the missing piece in the puzzle that entities connected to other networks are trying to put together. This shortcoming was underscored by Pierre St. Hilaire, Head of INTERPOL's Maritime Piracy Taskforce:

There is a large volume of information on piracy networks that is fragmented and in the possession of actors that have little past experience of working together closely. For example, information on piracy attacks and those responsible may be in the possession of the military; complementary information on the same attacks may be in the possession of the flag state, the ship owner, local law enforcement, crew members and hostages, and the private actors conducting the ransom negotiations. ${ }^{98}$

Mr. St. Hilaire added, "[p]oor communication among ship owners, navies, and law enforcement agencies means that it has been difficult to develop complete pictures of what happens in pirate attacks." 99

One suggested solution is to centralize the flow of information through the creation of a single information sharing mechanism. ${ }^{100}$ This mechanism should be comprised of two layers. The first layer would be on the national level, where each country should designate a single point of contact to facilitate domestic inter-agency coordination, ${ }^{101}$ as well as communication with external stakeholders. Such designation of "central authorities" has become standard practice in matters concerning international cooperation in criminal matters, ${ }^{102}$ and it has been proven to be efficient in preventing

98. St. Hilaire, supra note 73 , at 3 .

99. Id. at 2 n.2.

100. See $i d$. at 3 ("The ultimate goal is to collect and centralize this information for use by the law enforcement community.").

101. On the importance of coordination on the domestic level, see generally Brian Wilson, Reshaping Maritime Security Cooperation: The Importance of Interagency Coordination at the National Level, in Modern Piracy: Legal Challenges And Responses, supra note 41, at 202 ("In this context [of Somali piracy], cooperation between states is crucial. Recent efforts to repress piracy also demonstrate that cooperation within each state is equally crucial. Maritime security operations may involve extensive cooperation and coordination between different governmental agencies if they are to succeed.").

102. See supra notes 56, 57 and accompanying text (regarding the central information sharing centers discussed in the Djibouti and Gulf of Guinea Codes of Conduct). See also Article 32 of INTERPOL's Constitution, 
duplication of work, overcoming language barriers, and establishing informal personal relationships. Such informal personal relationships are often a key factor in facilitating effective and timely international cooperation. Along this line, Working Group 5, created in October 2011 under the auspices of the Contact Group on Piracy off the Coast of Somalia and focused on the investigation of financial flows related to piracy, ${ }^{103}$ recommended "the adoption of a single point of contact in each country to strengthen the domestic coordination process and to facilitate liaison with the private sector." ${ }^{104}$

Similarly, on the second layer, namely on the international level, a single empowered international mechanism - a "one stop shop"should be identified. This mechanism need not be created based on hierarchical structure vis-à-vis states and other contributing entities; rather, it should serve as an end-point and coordinator of all information sharing operations. With regard to communication regarding financial flows, Working Group 5 identified INTERPOL as "the main international single point of contact with the shipping industry for information-sharing to boost the international community's ability to identify, locate and prosecute pirates and their organizers and financiers." 105

Where information centers and networks have already been created, and identifying a single point of contact among them is not feasible, consideration should be given to integrating their work through applying an interoperability paradigm, namely identifying

according to which each member country appoints a body which will serve as the National Central Bureau (NCB). The NCB ensures liaison with: (1) the various departments in the country; (2) those bodies in other countries serving as National Central Bureaus; and (3) the Organization's General Secretariat. See INTERPOL, supra note 85, art. 32. See also conventions adopted under the auspices of the U.N., where, for the purpose of ensuring coordinated cooperation (for example, with regard to executing requests for mutual legal assistance) the conventions require each state party to designate a central authority. See, e.g., Convention Against Transnational Organized Crime art. 18.13, G.A. Res. 55/25, U.N. Doc. A/RES/55/25 (Nov. 15, 2000).

103. See Working Group 5, CGPCS, http://www.thecgpcs.org/work.do? action=workAd (last visited Mar. 7, 2013) ("Working Group 5, chaired by Italy, focuses on how to advance information sharing internationally and between industry and government authorities to disrupt the pirate enterprise ashore, and works with other key partners such as INTERPOL, national law enforcement/prosecution agencies currently pursuing piracy investigations/prosecution, and the World Bank to better understand how illicit financial flows associated with maritime piracy are moving in the area.").

104. See U.N. Secretary-General, Rep. of the Secretary-General Pursuant to Security Council Resolution 2020, ๆ 19, U.N. Doc. S/2012/783 (Oct. 22, 2012).

105. Id. 
means to connect and synchronize the various existing networks, thereby creating a "network of networks."106 From a technical perspective, this will ensure, for example, that a search in one system will generate responses from all other inter-connected networks and will therefore avoid the need to check each system individually.

Finally, the already existing international and regional structures for sharing piracy-related information can generally provide adequate support and meet the needs for information exchange. Accordingly, prior to creating a new center or network in this field, it is recommended that states carefully assess the added value in such an undertaking and ensure that this would not in fact exacerbate the already existing problems discussed above. Indeed, this cautious approach was echoed in recent international instruments. ${ }^{107}$

\section{Conclusion}

Maritime piracy has posed considerable risks to the international community. A key component for successful counter-piracy undertakings is international cooperation among states, international and regional organizations, and the private sector. The legal basis for international cooperation is moored in various international instruments, as well as in general principles of international law. It requires states to adhere to due diligence "best efforts" standards, which, in the context of maritime piracy, entail exercising sincere, concerted and proactive efforts.

Sharing information is one of the specific duties within the general duty to cooperate. It should therefore lead to a regular exchange of relevant data among all actors involved. Restrictions based on national security and classification rules should be applied only on an exceptional basis.

The implementation of a strategic partnership based on an interdisciplinary paradigm is not without difficulties, particularly in the field of information exchange and in light of the fact that the

106. See Slaughter, supra note 94, at 135 ("The best way to integrate the various governments networks . . . into a more recognizable structure of world order is to create networks of networks."). See also id. ch. 4, pt. 1 (discussing this idea further).

107. See, e.g., S.C. Res. 2039, supra note 4, 7 (encouraging "the States of the Gulf of Guinea, ECOWAS, ECCAS and GGC, to develop and implement transnational and transregional maritime security coordination centres covering the whole region of the Gulf of Guinea, building on existing initiatives, such as those under the auspices of the International Maritime Organization (IMO)" (emphasis added)); Gulf of Guinea Code of Conduct, supra note 57, pmbl. (emphasizing "the importance of building on existing national, regional and extraregional initiatives to enhance maritime safety and security in the Gulf of Guinea" (emphasis added)). 
primary actors - navies, law enforcement agencies, and the private sector - are not accustomed to working together. Nevertheless, through collaboration in recent years, many challenges have been successfully met, and solutions that have not been part of the traditional discourse in combating crimes were identified. To continue and build on those accomplishments, it is paramount to centralize the flow of information and to avoid the creation of new close-circuit information networks. 
